Article

\title{
Implications of Network Diversity for Venture Growth: The Mediation Effect of Entrepreneurial Alertness
}

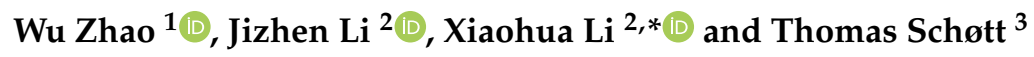 \\ 1 Xidian University, Xi'an 710126, China; zhsxwu@xidian.edu.cn \\ 2 School of Economics and Management, Tsinghua University, Beijing 100084, China; \\ lijzh@sem.tsinghua.edu.cn \\ 3 Department of Entrepreneurship and Relationship Management, Southern Denmark University, \\ Southern Denmark, Engstien 1, 6000 Kolding, Denmark; tsc@sam.sdu.dk \\ * Correspondence: lixh3.16@sem.tsinghua.edu.cn
}

Received: 27 September 2020; Accepted: 16 November 2020; Published: 23 November 2020

\begin{abstract}
This paper extends the conventional wisdom of social networks and entrepreneurship by clarifying the relationship between network diversity and venture growth as well as by studying the mediation effect of entrepreneurial alertness on network diversity. It highlights the importance of diverse networks for providing heterogeneous information and resources, which is the antecedent of entrepreneurial alertness. In this paper, Global Entrepreneurship Monitor (GEM) data from 44 countries are used in our analysis, considering the country's impact. Overall, we concluded that network diversity can significantly predict entrepreneurial alertness, and a venture's growth. Furthermore, an entrepreneur's educational level and entrepreneurial experience have positive moderating effects on the relationship between network diversity and entrepreneurial alertness.
\end{abstract}

Keywords: network diversity; entrepreneurship; performance

\section{Introduction}

Many scholars suggest that the growth of a venture can be more fully understood by examining its network of relationships [1,2], especially the network diversity. However, there is an ongoing debate on the relationship between network diversity and venture growth. On the one hand, many studies show that diverse networks can provide more information, advice, and resources, which are crucial for innovation and new business development [3]. Based on this assumption, previous studies have documented that entrepreneurs use social networks to identify entrepreneurial opportunities [4], which have a profound influence on venture growth. On the other hand, other studies have found that diverse networks may be detrimental for firms because heterogeneity makes the exchange of information difficult and engenders distrust, which increases the cost of maintaining diversity [5].

This paper aims to reconcile these two views by drawing on theories of social networks, entrepreneurial alertness, and an entrepreneur's human capital to clarify the specific mechanism by which network diversity affects entrepreneurial growth. Specifically, we examine whether and when start-ups with diverse ties are more likely to have higher growth rates and entrepreneurial alertness, because venture growth is not only dependent on the network per se, but also on the entrepreneur's opportunity alertness, through which firms gain promising opportunities [6]. Network impacts are also related to network capability [7] and network competence [8], a terminology used to "describe resources and preconditions, i.e., qualifications, skills, or knowledge necessary to perform certain tasks without considering the actual execution of the task" [6]. In the entrepreneurship scenario, network 
competence rests more upon entrepreneurs' capabilities since there is not a formal top management team in the earlier stage of most ventures. Therefore, we propose that entrepreneurial alertness may be influential in the relationship between network diversity and venture growth. Two human capital components are considered to condition our theory: entrepreneurial experience and educational level.

In addition to addressing this theoretical tension, this paper also intends to broaden our current understanding of network diversity in the context of entrepreneurship, because network diversity is critically important for start-ups to deal with the liability of newness [9]. A more fine-grained view of these factors' influences provides insights surrounding who has an easier path to becoming an entrepreneur and how an entrepreneur can sustain their career. This is of great interest to both academics and practitioners who intend to launch a business.

This paper tests its hypotheses by employing the Global Entrepreneurship Monitor (GEM) 2013 dataset, which contains entrepreneurs' network information. The results indicate that, on average, the start-ups with diverse networks can benefit more in the entrepreneurial process. The relationships between network diversity and venture growth are mediated by entrepreneurial alertness, reflecting an entrepreneur's capability to manage their network efficiently. Moreover, we examined the boundary condition of this mediation effect. Results show that part of the social network's effect can be substituted by the entrepreneur's human capital.

As noted above, this paper contributes to the entrepreneurship literature by deepening our understanding of the relationship between network diversity and venture growth. Going beyond a direct prediction of the nature of this relationship, this paper demonstrates the conditions under which the diversity of the theoretical mechanisms that drive a positive relationship vary, thereby providing a comprehensive and contingent perspective regarding venture decisions to pursue either a "focus strategy" or a "diverse strategy". We also extend entrepreneurship research by highlighting how entrepreneurs' human capital and social network jointly shape the firm's performance.

\section{Theory and Hypotheses}

\subsection{Network Diversity, Opportunity Identification, and Venture Growth}

From the social embeddedness perspective, all firms and individuals are embedded in society, thereby a start-up's performance is partly shaped by their early social ties (Gulati \& Gargiulo, 1999). Much literature focuses on the founder's or the venture team's social network's effect on the firm performance [10]. In general, prior studies have argued that networks differ in terms of their characteristics since it reflects the extent to which effective knowledge exchange and learning take place [11]. With specific regard to network diversity of entrepreneurs, social network theory suggests that several mechanisms might be responsible for the effect of entrepreneurs' network diversity on performance. Given the importance of knowledge for venture growth [12], Zahra, Ireland and Hitt (2000) [13] have proposed that a diverse network is a conduit of knowledge and assists with organizational learning as it pertains to most managers and entrepreneurs. Furthermore, entrepreneurs with more diverse networks are more innovative, obtain more information to improve the quality of strategic decision-making $[11,14]$ and form different small cliques to communicate, which allows entrepreneurs to procure resources at lower cost than they would in the open market [15]. Additionally, some scholars claim that social networks have a significant effect on venture growth, which can be explained by the differences and similarities among its network partners [5,16], regardless of the positive or negative impact. Extant literature has suggested that knowledge heterogeneity within a network could benefit managerial performance and creativity and innovativeness [17].

In sum, these mechanisms should result in a positive effect of an entrepreneur's network diversity on venture growth. In the small business context, there are some empirical supports for an overall positive relationship between an entrepreneur's network diversity and venture growth. For example, Uzzi (1999) found a positive association between a firm's network diversity and the possibility of finance 
by using data from America. Thus, based on propositions from the social embeddedness perspective, we propose that an entrepreneur's network diversity is positively related to venture growth.

Hypothesis 1. An entrepreneur's network diversity is positively related to venture growth.

It is important to note, however, that relatively little research has investigated the inside of the "black-box" that links network diversity with venture growth. We suggest that the positive relationship between network diversity and venture growth can be explained by entrepreneurial alertness. It is described as a cognitive capability to help entrepreneurs notice opportunities in the environment $[18,19]$. In this regard, entrepreneurs are different because of their capability to respond to external stimuli. Baron and Ward (2004) [20] made a large effort to bridge cognitive science and entrepreneurship research by clarifying the micro foundation of entrepreneurial alertness. Following their work, many scholars explored the antecedents of entrepreneurial alertness through a microlens. For example, Ardichvili and Cardozo (2003) [21] emphasize the significance of personality traits, social networks, and prior knowledge in predicting entrepreneurial alertness. Some scholars also recognize the importance of self-efficacy, entrepreneurial passion, technical ability, and market knowledge acquisition in determining an entrepreneur's alertness schema [22,23]. Others provide additional explanation by arguing the importance of a firm's path dependence [24] and external environmental complexity [25].

One's social network is an important channel to acquire information and knowledge and plays a significant role in cultivating entrepreneurial alertness. In general, entrepreneurial alertness increases with network diversity, and a stream of researchers emphasize the importance of information acquisition [26-28]. Using 4536 samples from Belgium and Finland, Arenius and Clerca (2005) [26] found that individuals who reside in big agglomerates, which means more diverse networks, are more likely to perceive opportunities compared to their counterparts. Ozgen and Baron (2007) [29] investigated the influence of different sources of information on opportunities alertness and also found the positive relationship between network diversity and opportunities alertness. Similar to these findings, we propose that the more diverse entrepreneurs' networks are, the more they will be alerted to opportunities.

Hypothesis 2. An entrepreneur's network diversity is positively related to entrepreneurial alertness.

We further argue that entrepreneurial alertness and venture growth are positively related. Tang, Kacmar [30] define entrepreneurial alertness as the combination of three distinct elements, that is, scanning and searching for information, connecting previously disparate information, and evaluating the existence of profitable business opportunities. Therefore, entrepreneurial alertness itself is a process of pursuing profit in terms of introducing new products or services to the market [31,32]. Introducing new products or services is an important source for venture growth. On one hand, it creates ventures with the innovative capability differentiating themselves from others and strengthens a venture's competitive advantage. On the other hand, the growth paths of many ventures are supported by venture capital. The possibility of a venture's access to venture capital depends, at least in part, on the entrepreneur's attributes-opportunity alertness. This argument is evidenced by a manager of a venture capital institution (VC) we interviewed; the manager indicated three important factors VC institutions value: the founder's attributes, the founding team, and unit time efficiency. In conclusion, we hypothesize that entrepreneurial alertness is positively related to venture growth.

Hypothesis 3. Entrepreneurial alertness is positively related to venture growth.

We note that network diversity is beneficial for entrepreneurial alertness, through which the entrepreneur can access more exemplars for comparison purposes. Network diversity is an informal structure which helps to manage a venture's interaction with the environment. For example, 
network diversity contributes to generating novel ideas that achieve higher levels of product quality, develop better marketing methods [33], and discover potential downsides of current business models. Furthermore, some scholars argued that network diversity helps to increase entrepreneurial alertness through developing an effective vision, which in turn, affects subsequent venture growth. We examine entrepreneurial alertness as one mechanism through which network diversity has a mediating effect on venture growth because our study pays close attention to the early stage of the entrepreneurial process. We have discussed the function of network diversity for entrepreneurial alertness. Furthermore, we have hypothesized a relationship between entrepreneurial alertness and venture growth. Therefore, entrepreneurial alertness should be a mechanism through which network diversity acts on venture growth.

Hypothesis 4. Entrepreneurial alertness mediates the positive relationship between an entrepreneur's network diversity and venture growth.

\subsection{Role of Human Capital}

As discussed above, network diversity helps entrepreneurs to construct their social networks and gain access to diverse information proactively, providing them with the cognitive recognition pattern to involve them in opportunity searching. We further discuss how entrepreneurs' diverse networks interact with human capital to predict opportunity alertness [11,34].

\subsubsection{Entrepreneurial Experience}

Knowledge increases individual ability, leading to large potentials to perceive profitable opportunities existent in one's environment [11,35]. Knowledge acquired from life experience and formal education could be internalized into individuals and could exert an implicit effect on cognitive patterns, which is the core opinion of human capital theory [36]. Opportunities alertness is one of the behaviors that varies across different education, experience, gender, age, and personality [30]. The influence of one's knowledge or recognition pattern in entrepreneurship can be amplified or inhibited since knowledge and skills learned from different social categories direct and bias individual behavioral tendencies [37]. Among all human capital components, we expect entrepreneurial experience and education to be closely related to opportunity alertness.

Entrepreneurial experience is one of the human capital factors which measures an individual's prior knowledge, creating the "knowledge corridor" that allows him/her to be sensitive to certain opportunities, but not others. Experience is initially discussed on work experience, industry-specific experience, and self-employment experience $[36,38]$. However, a growing number of scholars suggest entrepreneurial-specific experience should be considered to illustrate the whole process $[38,39]$. On one hand, entrepreneurial experience includes managerial experiences, reputation, social, and business networks that can be used to identity or pursuit promising opportunities [40]. On the other hand, some scholars detected that more experienced entrepreneurs had more business sense that reflects as a kind of tacit knowledge, guiding the exploration of opportunity.

In the entrepreneurship literature, experience is often considered as an indicator of self-efficacy [41], that is, belief in one's own venture business. Self-efficacy is considered to be a state-like characteristic related to actual ability and has a significant influence on individual cognition and behavior [36,42]. Individuals with high self-efficacy tend to persist toward the achievement of goals and have higher job satisfaction, even under stressful and uncertain circumstances. This is particularly the case in the entrepreneurship field.

In addition, prior entrepreneurial experience represents not only individuals' psychological characteristics, but also their capabilities to run a business. As suggested by Li and Zhang (2007), a manager's experience enables ventures to more efficiently develop and improve their capabilities in evaluating the potential of a business [43]. For example, Eisenhardt and Schoonhoven (1990) [44] found that the manager's experience makes decision-making more efficient and improves individuals' 
abilities to communicate with each other [44]. Moreover, managers are more likely to understand the strengths of their teams. Managers can save time building trust (Stinchcombe, 1965) and they can quickly identify the appropriate people needed by the firm. This is a fairly important aspect for ventures-to enhance organizational capability when they lack a formal top management team or formal organizational structure. Also, enhanced market competition and dynamics have created the need for managerial expertise [45]. Therefore, attributes of entrepreneurship place considerable weight on the role of prior experience in exploring new opportunities, recruiting candidates, understanding the markets, and satisfying customer needs.

In short, entrepreneurial experience, to some extent, is viewed as an element of one's social network, by which entrepreneurs can gain advantages with the increased cognitive ability to be alert to opportunity, but that is redundant to the effect of having a diverse network on opportunity alertness. We thus propose the following hypothesis.

Hypothesis 5. The positive effects of network diversity on opportunity alertness diminish with the increase of entrepreneurial experience.

\subsubsection{Education}

Education is one of the most frequently tested factors of human capital. Scholars highlight the knowledge, subskill and learning ability entrepreneurs acquired from education in regards to its influence on entrepreneurs' capability of management and opportunities alertness [46,47], as well as its benefits for innovativeness [48]. In addition, a higher educational level often benefits entrepreneurs by increasing organizational legitimacy and mitigating the risks of newness, because their academic reputation will be considered as a factor to predict the venture's growth potential; this is an important phenomenon discussed in academic entrepreneurship literature [49].

However, as a formal education channel, what an entrepreneur gains from it-information, resources, skills, cognitive pattern-is the same as an informal network provides. In this sense, it can be replaced by diverse networks. Some scholars may claim that education also provides the basic cognitive skills to adapt to environmental change [50]. In contrast, formal education may cultivate attitudes that are antithetical to entrepreneurship [51]. For example, education might be detrimental to entrepreneurs in terms of risk-taking, which is decided by an individual's career choice. Over-investment in education leads to high levels of certification, giving the entrepreneur strong motivation to protect what they have owned, and discouraging entrepreneurship with high uncertainty [52]. Therefore, it is reasonable to predict that individuals with higher-level education are likely to constrain their cognitive patterns in a manner that contradicts characteristics of entrepreneurship; thus we propose the following hypothesis.

Hypothesis 6. The positive effects of network diversity on opportunity alertness diminish with the increase of educational level.

\section{Research Design}

\subsection{Data Sources and Sample}

The main data source used for quantitative analysis is the Global Entrepreneurship Monitor (GEM) 2009-2013 dataset. GEM began in 1999 as a joint research project between Babson College (USA) and the London Business School (UK). The GEM Global Report was published annually during the past decade (https://www.gemconsortium.org/data). Data collection for this study is by structured questionnaires designed by the GEM national expert team; these experts are also responsible for the data collection process, which is guided by GEM quality standards [53]. The questionnaire is translated into appropriate language, and is then coded into the format required by standards. The GEM 2009-2013 dataset comprises entrepreneurship propensity data of 25,283 entrepreneurs in 51 countries. To control the potential influence of country-level factors, we further collected the public data of macroeconomic 
indicators from the World Bank. These are normalized to a per capita basis to allow for hypothesis testing across the cross-section of 51 countries. The diverse data in our sample allows us to compare entrepreneurship under different contexts, such as government support, entrepreneurial education, and also cultural inclusion for entrepreneurial activities.

\subsection{Analytical Strategy}

Regression analysis was used to test our hypotheses. The Stata 14 software package was employed so that we were able to conduct testing for mediation effects and moderation effects. We used two approaches to test our mediation hypothesis. First, we employed the conventional method [54]: (1) the independent variable significantly affected the dependent variable in the absence of a mediator; (2) the mediator significantly affected the dependent variable; (3) the independent variable significantly affected the mediator; (4) the significant effect of the independent variable on the dependent variable diminished when the mediator was added to the model. Second, we examined the mediation effect using a Sobel-Goodman test [55].

\subsection{Measures}

Dependent variable. There is considerable debate about how to measure entrepreneurial growth [56]. The mainstream view is that firms are fundamentally concerned with economic results, and popular measures are profits, revenues, market share, and sales; these do not always apply to start-ups [39] since some of the start-up are no longer operating as an independent entity. Number of employees is widely considered a key indicator of venture growth [57] since financial data is difficult to obtain for startups. We used entrepreneurs' expected growth of the number of employees to measure venture growth since their expectation is based on the venture's past performance; thus, it largely captures a venture's actual growth. Respondents were asked to state "Not counting the owners, how many people are currently working for this business" (5yrjob) and "Not counting owners, how many people will be working for this business five years from now" (nowjob). Venture growth was calculated as $\log (1+5$ yrjob $)-\log (1+$ nowjob $)$.

Independent variable. Consistent with diversity literature, the advice network diversity of each entrepreneur was measured by using Blau's (1977) index of heterogeneity [58], $1-\sum\left[\left(p_{i}\right)\right]^{2}$, where i varies from 1 to 5 , and $p_{i}$ is the portion of an entrepreneur's advice tie in the ith category (e.g., (Uzzi, 1999b; William A. Kelly, 1981)). There are 20 kinds of advice tie in our sample. The categories were created based on connections to different subjects and they were divided into five types. Advice ties included a private tie, workplace tie, international tie, professional tie, and market tie. These areas were verified by expertise within the network field. We then calculated each entrepreneur's network diversity by following the Blau formula. The calculation is:

Network diversity $=1-\left[((\text { no. of private ties }) /(\text { total ties }))^{2}+((\text { no. of workplace ties }) /(\text { total ties }))^{2}\right.$

$+((\text { no. of international ties }) /(\text { total ties }))^{2}+((\text { no. of professional ties }) /(\text { total ties }))^{2}$

$\left.+((\text { no. of market ties }) /(\text { total ties }))^{2}\right]$

The minimum and maximum diversity indexes (theoretically ranging from 0 to 1 ) were 0 and 0.8 , respectively, with high scores representing greater diversity, and the average network diversity was 0.38 .

Mediator. Following Levie and Autio's (2008) measurement of entrepreneurial alertness (Alertness) [59], we used the opportunity alertness designed in the GEM questionnaire as our measurement. Specifically, respondents are asked to state "In the next six months, will there be good opportunities for starting a business in the area where you live?".

Moderators. Following prior research, entrepreneurial experience (experience) measures whether the entrepreneur has the knowledge, skill, and experience required to start a new business; 1 indicates yes, and 0 indicates no. The respondents are asked to provide their educational level, defined as years of education, represented by education. 
Control variables. For the country level, it may be the economic development, entrepreneurial culture (Culture), market dynamic (Marketdyna) and market openness (Marketopen) that are closely related to entrepreneurial performance; we added these controls. Economic development was measured as the gross domestic product (GDP). Entrepreneurial culture was measured by using the "cultural and social norms" in GEM country-level data; it measures a country's social approval of entrepreneurship. Market dynamics and market openness were also sourced from the GEM dataset, representing the market characteristics in a country. For the firm level, given that a common finding in prior studies was that organization size, age, and the industry they belong to are strongly associated with performance (e.g., Chatterjee \& Hambrick, 2007 [60]), these three elements were included as control variables. According to prior research, firm size is measured as the number of employees (Size). Also, we control a new venture's phase (represented by Phase, $1=$ operate, $0=$ start), with regards to the specifically entrepreneurial context. The number of owners of the venture (Owners) is controlled because of its relationship with potential social networks. For the individual level, we control the entrepreneur's age, gender $(1=$ female, $0=$ male), and risk propensity (represented by Risk, $1=$ risk, 0 = conservative). Entrepreneurship always involves motivation which has a direct effect on entrepreneurial performance [57]. We divided entrepreneurial motivation into two categories based on GEM: 1 indicates opportunity entrepreneurship, and 0 indicates necessity entrepreneurship, represented by Reasonop.

\section{Results}

Table 1 presents the means, standard deviations, and correlations among the study variables. GDP was taken as a log transformation to satisfy the common variance assumption. Overall, the correlations among the independent variables are relatively modest, ranging from -0.612 to 0.726. In order to guard against potential multicollinearity between variables, we computed all the full model variances inflation factors (VIFs); the mean VIF is 3.32, which is less than 10.

Table 1. Data description.

\begin{tabular}{|c|c|c|c|c|c|c|c|c|}
\hline & Growth & Alertness & Diversity & Education & $\operatorname{lnGDP}$ & Culture & Markopen & Markdyna \\
\hline Growth & 1 & & & & & & & \\
\hline Alertness & $0.120 * * *$ & 1 & & & & & & \\
\hline Diversity & $0.211^{* * *}$ & $0.054^{* * *}$ & 1 & & & & & \\
\hline Education & $0.175 * * *$ & $-0.051 * * *$ & $0.201 * * *$ & 1 & & & & \\
\hline $\operatorname{lnGDP}$ & $0.102 * * *$ & $-0.136^{* * *}$ & $0.154^{* * *}$ & $0.406^{* * *}$ & 1 & & & \\
\hline Culture & $-0.108^{* * *}$ & $0.107^{* * *}$ & $-0.044^{* * *}$ & $-0.116^{* * *}$ & $-0.203 * * *$ & 1 & & \\
\hline Markopen & $-0.157^{* * *}$ & 0.00900 & $-0.048^{* * *}$ & $-0.105^{* * *}$ & $-0.205 * * *$ & $0.363^{* * *}$ & 1 & \\
\hline Markdyna & $-0.254^{* * *}$ & $-0.051^{* * *}$ & $-0.054^{* * *}$ & $-0.125^{* * *}$ & $-0.322 * * *$ & $0.311^{* * *}$ & $0.284^{* * *}$ & 1 \\
\hline Phase & $-0.555^{* * *}$ & $-0.089 * * *$ & $-0.074^{* * *}$ & $-0.119^{* * *}$ & $-0.103^{* * *}$ & $0.131^{* * *}$ & $0.115^{* * *}$ & $0.255^{* * *}$ \\
\hline Firm age & $-0.462 * * *$ & $-0.125^{* * *}$ & $-0.091^{* * *}$ & $-0.154^{* * *}$ & $-0.079 * * *$ & $0.114^{* * *}$ & $0.073 * * *$ & $0.226^{* * *}$ \\
\hline Size & $-0.337^{* * *}$ & $-0.040^{* * *}$ & $0.107^{* * *}$ & $0.111^{* * *}$ & $0.095^{* * *}$ & $0.023 * * *$ & $0.023^{* * *}$ & $0.112^{* * *}$ \\
\hline Owner & $0.215^{* * *}$ & 0 & $0.176^{* * *}$ & $0.208^{* * *}$ & $0.192^{* * *}$ & $-0.102 * * *$ & $-0.042 * * *$ & $-0.144^{* * *}$ \\
\hline Age & $-0.158^{* * *}$ & $-0.108^{* * *}$ & $-0.047^{* * *}$ & $-0.085^{* * *}$ & $0.099^{* * *}$ & -0.00200 & $-0.019 * * *$ & 0.010 * \\
\hline Reasonop & $0.141^{* * *}$ & $0.092^{* * *}$ & $0.108^{* * *}$ & $0.190 * * *$ & $0.081^{* * *}$ & $0.052 * * *$ & $-0.043^{* * *}$ & $-0.079 * * *$ \\
\hline Risk & $0.090 * * *$ & $0.124^{* * *}$ & $0.023^{* * *}$ & $0.016^{* * *}$ & $0.017^{* * *}$ & $-0.034^{* * *}$ & $-0.023^{* * *}$ & $-0.073^{* * *}$ \\
\hline \multirow[t]{2}{*}{ Gender } & $-0.071^{* * *}$ & $-0.012 *$ & $-0.092^{* * *}$ & $-0.068^{* * *}$ & $-0.055^{* * *}$ & $0.057^{* * *}$ & 0.00700 & $0.017^{* * *}$ \\
\hline & Phase & Firm age & Size & Owner & Age & Reasonop & Risk & Gender \\
\hline Phase & 1 & & & & & & & \\
\hline Firm age & $0.726^{* * *}$ & 1 & & & & & & \\
\hline Size & $0.547 * * *$ & $0.346^{* * *}$ & 1 & & & & & \\
\hline Owner & $-0.151^{* * *}$ & $-0.160 * * *$ & $0.089 * * *$ & 1 & & & & \\
\hline Age & $0.185^{* * *}$ & $0.321^{* * *}$ & $0.103^{* * *}$ & $-0.088^{* * *}$ & 1 & & & \\
\hline Reasonop & $-0.090^{* * *}$ & $-0.103^{* * *}$ & $0.041^{* * *}$ & $0.086^{* * *}$ & $-0.072^{* * *}$ & 1 & & \\
\hline Risk & $-0.054^{* * *}$ & $-0.080^{* * *}$ & -0.00100 & 0.00800 & $-0.054^{* * *}$ & $0.069^{* * *}$ & 1 & 1 \\
\hline Gender & -0.00600 & $-0.014^{* *}$ & $-0.115^{* * *}$ & $-0.052^{* * *}$ & $-0.014^{* *}$ & $-0.076^{* * *}$ & $-0.019^{* * *}$ & \\
\hline
\end{tabular}


Table 2 displays the results obtained from modeling entrepreneurial growth. Model 1 provides a baseline model that includes all control variables. Model 2 includes the network diversity variable, and Models 3-5 include the mediation variables. Models 6-7 show the moderating effect of human capital.

Hypotheses 1 and 2 proposed the influence of network diversity on venture growth performance and entrepreneurial alertness. Table 2 shows, after controlling for country-level variables, an entrepreneur's demographic variables; network diversity was positively related to venture growth ( $\beta=0.159, p<0.01$, Model 2) and entrepreneurial alertness $(\beta=0.126, p<0.01$, Model 3$)$. Thus, both Hypotheses $\mathrm{H} 1$ and $\mathrm{H} 2$ were supported.

Table 2. Regression model.

\begin{tabular}{|c|c|c|c|c|c|c|c|}
\hline Variables & Model 1 & Model 2 & Model 3 & Model 4 & Model 5 & Model 6 & Model 7 \\
\hline Diversity & & $\begin{array}{c}0.159^{* * *} \\
(0.005)\end{array}$ & & $\begin{array}{c}0.126^{* * *} \\
(0.015)\end{array}$ & $\begin{array}{c}0.156^{* * *} \\
(0.005)\end{array}$ & $\begin{array}{c}0.243^{* * *} \\
(0.032)\end{array}$ & $\begin{array}{c}0.200 * * * \\
(0.034)\end{array}$ \\
\hline Alertness & & & $\begin{array}{c}0.128^{* * *} \\
(0.012)\end{array}$ & & $\begin{array}{c}0.110 * * * \\
(0.011)\end{array}$ & & \\
\hline Experience & & & & & & $\begin{array}{c}0.829 * * * \\
(0.037)\end{array}$ & \\
\hline Diversity ${ }^{*}$ Experience & & & & & & $\begin{array}{c}-0.171^{* * *} \\
(0.035)\end{array}$ & \\
\hline Education & & & & & & & $\begin{array}{c}-0.017^{* * * *} \\
(0.003)\end{array}$ \\
\hline Education * Diversity & & & & & & & $\begin{array}{c}-0.007^{* *} \\
(0.003)\end{array}$ \\
\hline GDP & $\begin{array}{c}0.016^{* *} \\
(0.006)\end{array}$ & $\begin{array}{c}0.002 \\
(0.006)\end{array}$ & $\begin{array}{c}0.027 * * * \\
(0.006)\end{array}$ & $\begin{array}{c}-0.423 * * * \\
(0.018)\end{array}$ & $\begin{array}{l}0.012 * \\
(0.006)\end{array}$ & $\begin{array}{c}-0.411^{* * *} \\
(0.018)\end{array}$ & $\begin{array}{c}-0.394^{* * *} \\
(0.019)\end{array}$ \\
\hline Culture & $\begin{array}{c}0.123^{* * *} \\
(0.020)\end{array}$ & $\begin{array}{c}0.126^{* * *} \\
(0.020)\end{array}$ & $\begin{array}{c}0.097^{* * *} \\
(0.020)\end{array}$ & $\begin{array}{c}0.951^{* * *} \\
(0.053)\end{array}$ & $\begin{array}{c}0.104^{* * *} \\
(0.020)\end{array}$ & $\begin{array}{c}0.998^{* * *} \\
(0.054)\end{array}$ & $\begin{array}{c}0.941^{* * *} \\
(0.053)\end{array}$ \\
\hline Markopen & $\begin{array}{c}-0.373^{* * *} \\
(0.024)\end{array}$ & $\begin{array}{c}-0.356^{* * *} \\
(0.024)\end{array}$ & $\begin{array}{c}-0.368^{* * *} \\
(0.024)\end{array}$ & $\begin{array}{c}-0.196^{* * *} \\
(0.064)\end{array}$ & $\begin{array}{c}-0.352^{* * *} \\
(0.024)\end{array}$ & $\begin{array}{c}-0.231^{* * *} \\
(0.064)\end{array}$ & $\begin{array}{c}-0.206^{* * *} \\
(0.064)\end{array}$ \\
\hline Markdyna & $\begin{array}{c}-0.132 * * * \\
(0.013)\end{array}$ & $\begin{array}{c}-0.133^{* * * *} \\
(0.013)\end{array}$ & $\begin{array}{c}-0.119^{* * *} \\
(0.013)\end{array}$ & $\begin{array}{c}-0.454^{* * * *} \\
(0.035)\end{array}$ & $\begin{array}{c}-0.122 * * * \\
(0.013)\end{array}$ & $\begin{array}{c}-0.409 * * * \\
(0.035)\end{array}$ & $\begin{array}{c}-0.443^{* * *} \\
(0.035)\end{array}$ \\
\hline Phase & $\begin{array}{c}-0.781^{* * *} \\
(0.018)\end{array}$ & $\begin{array}{c}-0.751^{* * * *} \\
(0.018)\end{array}$ & $\begin{array}{c}-0.777^{* * *} \\
(0.018)\end{array}$ & $\begin{array}{c}0.041 \\
(0.053)\end{array}$ & $\begin{array}{c}-.749^{* * *} \\
(0.018)\end{array}$ & $\begin{array}{c}-0.096^{*} \\
(0.050)\end{array}$ & $\begin{array}{c}-0.127^{* * * *} \\
(0.049)\end{array}$ \\
\hline Firm age & $\begin{array}{c}-0.090^{* * *} \\
(0.007)\end{array}$ & $\begin{array}{c}-0.085^{* * *} \\
(0.007)\end{array}$ & $\begin{array}{c}-0.086^{* * *} \\
(0.007)\end{array}$ & $\begin{array}{c}0.039 \\
(0.064)\end{array}$ & $\begin{array}{c}-0.081^{* * *} \\
(0.007)\end{array}$ & $\begin{array}{c}-0.128^{* * *} \\
(0.019)\end{array}$ & $\begin{array}{c}-0.153^{* * *} \\
(0.019)\end{array}$ \\
\hline Size & $\begin{array}{c}-0.153^{* * *} \\
(0.008)\end{array}$ & $\begin{array}{c}-0.178^{* * *} \\
(0.008)\end{array}$ & $\begin{array}{c}-0.155^{* * *} \\
(0.008)\end{array}$ & $\begin{array}{c}0.111^{* *} \\
(0.047)\end{array}$ & $\begin{array}{c}-0.180^{* * *} \\
(0.008)\end{array}$ & $\begin{array}{c}0.018 \\
(0.021)\end{array}$ & $\begin{array}{c}0.061^{* * *} \\
(0.021)\end{array}$ \\
\hline Owners & $\begin{array}{c}0.275^{* * *} \\
(0.011)\end{array}$ & $\begin{array}{c}0.239 * * * \\
(0.011)\end{array}$ & $\begin{array}{c}0.276^{* * *} \\
(0.011)\end{array}$ & $\begin{array}{c}-0.119 \text { ** } \\
(0.049)\end{array}$ & $\begin{array}{c}0.240 * * * \\
(0.011)\end{array}$ & $\begin{array}{c}-0.036 \\
(0.030)\end{array}$ & $\begin{array}{c}-0.051 * \\
(0.030)\end{array}$ \\
\hline Age & $\begin{array}{c}-0.003^{* * *} \\
(0.000)\end{array}$ & $\begin{array}{c}-0.003^{* * *} \\
(0.000)\end{array}$ & $\begin{array}{c}-0.003^{* * *} \\
(0.000)\end{array}$ & $\begin{array}{c}-0.149^{* * *} \\
(0.019)\end{array}$ & $\begin{array}{c}-0.002^{* * *} \\
(0.000)\end{array}$ & $\begin{array}{c}-0.009^{* * *} \\
(0.001)\end{array}$ & $\begin{array}{c}-0.010^{* * *} \\
(0.001)\end{array}$ \\
\hline Gender & $\begin{array}{c}-0.127^{* * *} \\
(0.011)\end{array}$ & $\begin{array}{c}-0.110^{* * *} \\
(0.011)\end{array}$ & $\begin{array}{c}-0.125^{* * *} \\
(0.011)\end{array}$ & $\begin{array}{c}-0.079 * * * \\
(0.029)\end{array}$ & $\begin{array}{c}-0.108^{* * *} \\
(0.011)\end{array}$ & $\begin{array}{c}-0.068^{* *} \\
(0.030)\end{array}$ & $\begin{array}{c}-0.082^{* * *} \\
(0.029)\end{array}$ \\
\hline Reasonop & $\begin{array}{c}0.151^{* * *} \\
(0.011)\end{array}$ & $\begin{array}{c}0.130 * * * \\
(0.011)\end{array}$ & $\begin{array}{c}1.895^{* * *} \\
(0.011)\end{array}$ & $\begin{array}{c}0.051 \text { ** } \\
(0.021)\end{array}$ & $\begin{array}{c}0.124^{* * *} \\
(0.011)\end{array}$ & $\begin{array}{c}0.241^{* * *} \\
(0.030)\end{array}$ & $\begin{array}{c}0.289 * * * \\
(0.029)\end{array}$ \\
\hline Risk & $\begin{array}{c}0.114 * * * \\
(0.012)\end{array}$ & $\begin{array}{c}0.113^{* * *} \\
(0.011)\end{array}$ & $\begin{array}{c}0.100 * * * \\
(0.012)\end{array}$ & $\begin{array}{c}-0.065 * * \\
(0.030)\end{array}$ & $\begin{array}{c}0.101 * * * \\
(0.011)\end{array}$ & $\begin{array}{c}0.391 * * * \\
(0.031)\end{array}$ & $\begin{array}{c}0.513 * * * \\
(0.030)\end{array}$ \\
\hline Industry & $\sqrt{ }$ & $\sqrt{ }$ & $\sqrt{ }$ & $\sqrt{ }$ & $\sqrt{ }$ & $\sqrt{ }$ & $\sqrt{ }$ \\
\hline $\begin{array}{c}\text { Year } \\
\text { Constant }\end{array}$ & $\begin{array}{c}\sqrt{ } \\
2.040^{* * *} \\
(0.114)\end{array}$ & $\begin{array}{c}\sqrt{ } \\
2.108^{* * *} \\
(0.112)\end{array}$ & $\begin{array}{c}\sqrt{ } \\
1.895^{* * *} \\
(0.114)\end{array}$ & $\begin{array}{c}\sqrt{ } \\
3.124^{* * *} \\
(0.302)\end{array}$ & $\begin{array}{c}\sqrt{ } \\
1.982^{* * *} \\
(0.112)\end{array}$ & $\begin{array}{c}\sqrt{ } \\
2.273^{* * *} \\
(0.308)\end{array}$ & $\begin{array}{c}\sqrt{ } \\
3.032^{* * *} \\
(0.302)\end{array}$ \\
\hline Observations & 25,283 & 25,283 & 25,283 & 25,283 & 25,283 & 25,283 & 25,283 \\
\hline
\end{tabular}

Hypotheses 3 and 4 posited that entrepreneurial opportunity alertness mediated the relationship between network diversity and venture growth. As shown in Table 2, in the presence of a control variable, entrepreneurial alertness is positively related to venture growth $(\beta=0.128, p<0.01$, Model 4$)$. After control the mediator, the effect of the independent variable (network diversity) diminished ( $\beta=0.156, p<0.01$, Model 5 ). We also conducted a Sobel test to examine the mediation effect; results show that the t-statistic is $7.50(p<0.01)$. We thus found support for Hypotheses 3 and 4 . 
Hypothesis 5 argued that prior entrepreneurial experience moderated the relationship between network diversity and entrepreneurial alertness. The interaction between network diversity and the prior entrepreneurial experience was negatively related to entrepreneurial alertness $(\beta=-0.171$, $p<0.01$, Model 6). This suggests that network diversity is more strongly associated with entrepreneurial alertness for entrepreneurs who were low in prior experience. Also, we employ the same procedure to test Hypothesis 6; it posited that education moderates the relationship between network diversity and opportunity alertness. The results showed that the moderation effect is statistically significant ( $\beta=0.017, p<0.01$, Model 7 ). To visualize the moderating effect on entrepreneurial alertness, the interaction between network diversity and entrepreneurial experience, and network diversity and education are plotted in Figures 1 and 2. It suggests that network diversity was more strongly associated with entrepreneurial alertness for entrepreneurs who did not have entrepreneurial experience and who were low in educational levels. In summary, Hypotheses 5 and 6 were supported.

To check the robustness of our results. We replaced network diversity with an alternative measure based on the indices of richness/variety proposed by Shannon and Weaver (1951) [61], which is also used in the managerial field [62]. The Shannon index is calculated as $\left(-\sum_{i=1}^{n} p_{i} \log \left(p_{i}\right)\right)$, where $\mathrm{n}$ is the total number of social ties, $p_{i}$ is the proportion of $i$ th type in the $i$ type, and log is the natural logarithm. Many of our samples did not have any ties in one kind of social tie, which led to many zero values, so we changed the formula to $\left(-\sum_{i=1}^{n} p_{i} \log \left(1+p_{i}\right)\right)$ to avoid the null value. Table 3 shows the results of a robust check, and the inclusion of this alternative measure of network diversity did not change our results.

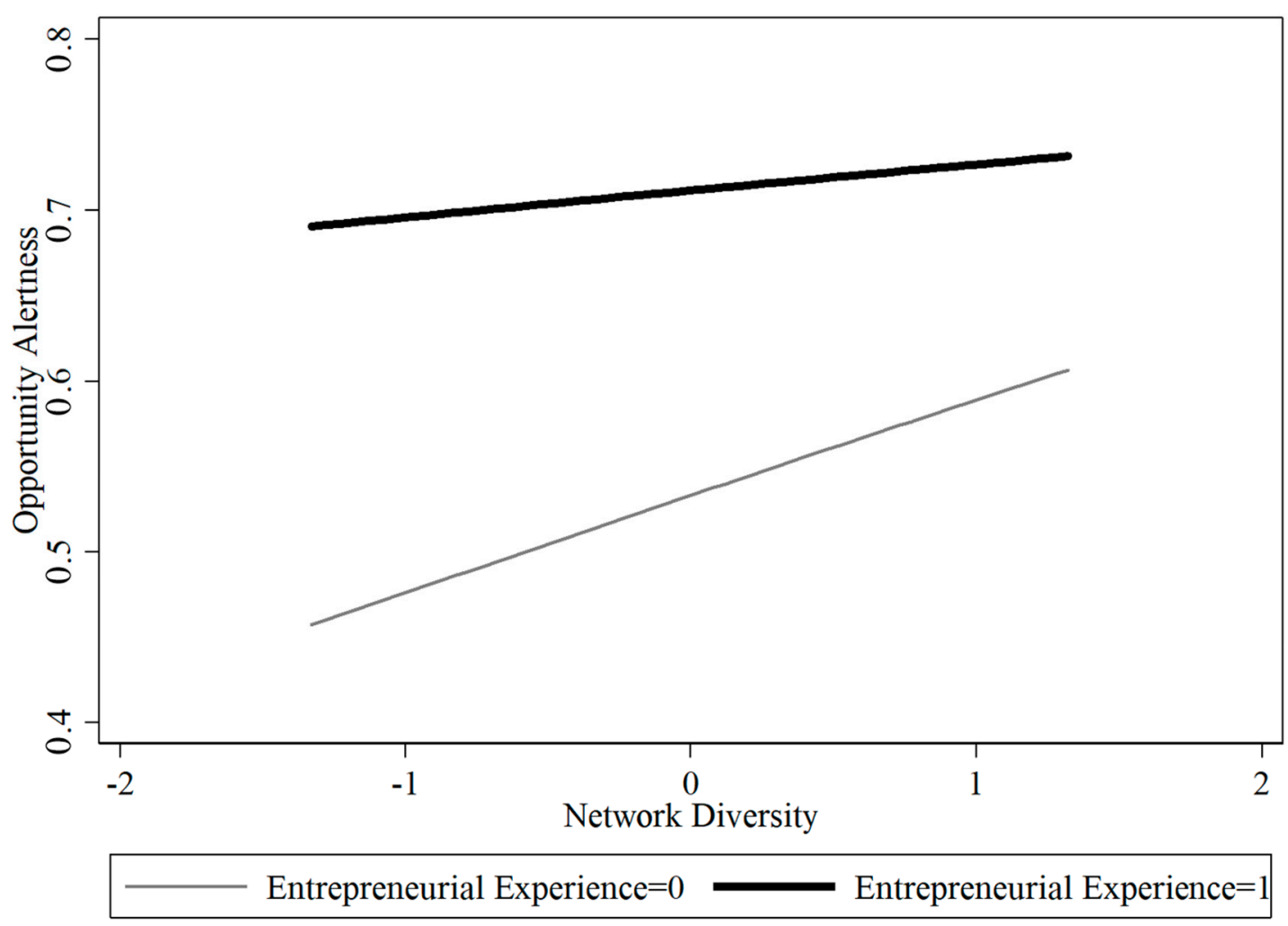

Figure 1. Interaction of network diversity and entrepreneurial experience. 


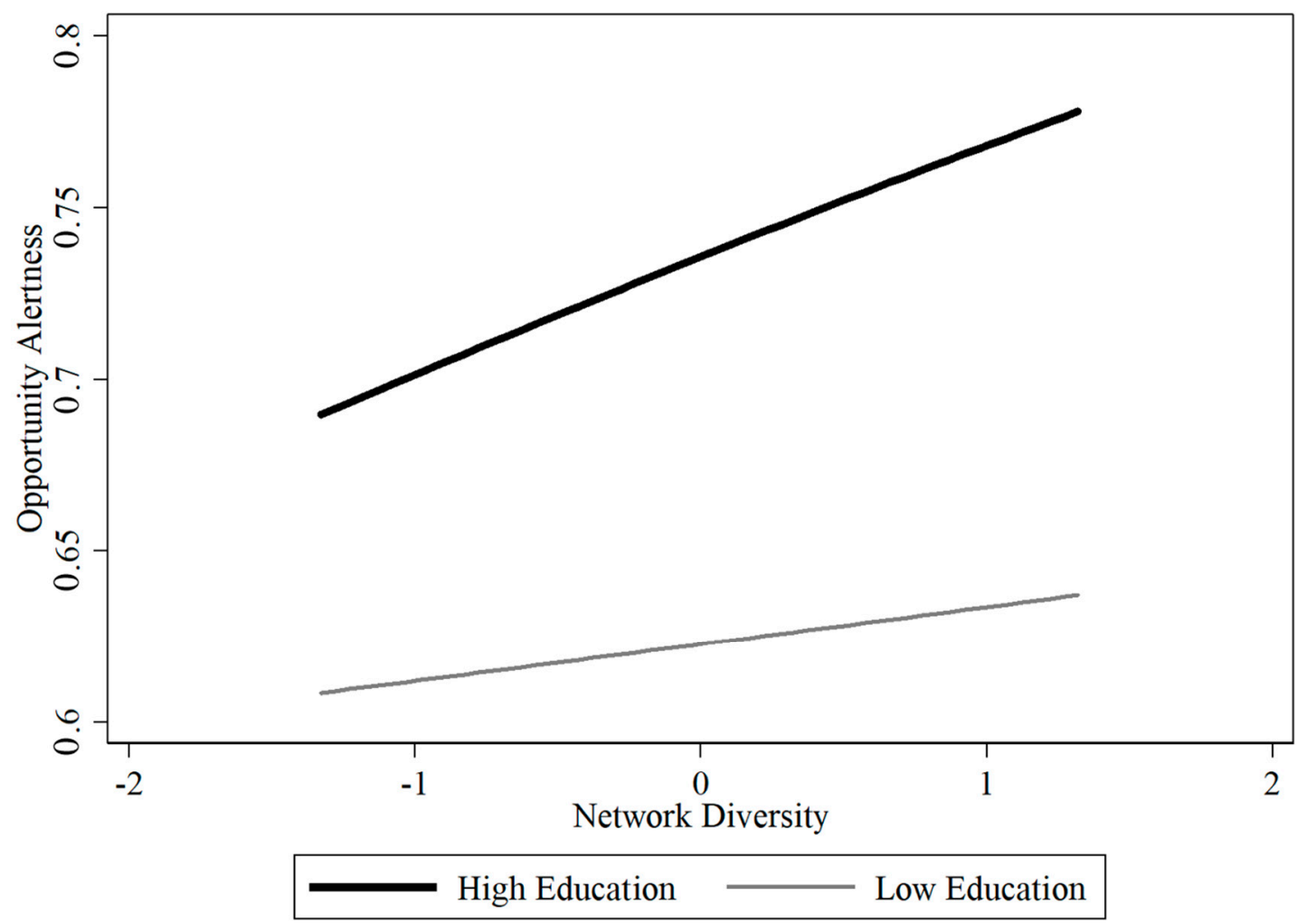

Figure 2. Interaction of network diversity and education.

Table 3. Robustness check.

\begin{tabular}{|c|c|c|c|c|c|c|c|}
\hline Variables & Model 1 & Model 2 & Model 3 & Model 4 & Model 5 & Model 6 & Model 7 \\
\hline Diversity & & $\begin{array}{c}0.162 * * * \\
(0.005)\end{array}$ & & $\begin{array}{c}0.129 * * * \\
(0.015)\end{array}$ & $\begin{array}{c}0.160 * * * \\
(0.005)\end{array}$ & $\begin{array}{c}0.249 * * * \\
(0.032)\end{array}$ & $\begin{array}{c}0.208^{* * *} \\
(0.035)\end{array}$ \\
\hline Alertness & & & $\begin{array}{c}0.128^{* * *} \\
(0.012)\end{array}$ & & $\begin{array}{c}0.109 * * * \\
(0.011)\end{array}$ & & \\
\hline Experience & & & & & & $\begin{array}{c}0.828^{* * *} \\
(0.037)\end{array}$ & \\
\hline Diversity * Experience & & & & & & $\begin{array}{c}-0.175^{* * *} \\
(0.036)\end{array}$ & \\
\hline Education & & & & & & & $\begin{array}{c}-0.017^{* * *} \\
(0.003)\end{array}$ \\
\hline Education * Diversity & & & & & & & $\begin{array}{c}-0.007^{* *} \\
(0.003)\end{array}$ \\
\hline GDP & $\begin{array}{c}0.016^{* *} \\
(0.006)\end{array}$ & $\begin{array}{c}0.001 \\
(0.006)\end{array}$ & $\begin{array}{c}0.027^{* * *} \\
(0.006)\end{array}$ & $\begin{array}{c}-0.424^{* * *} \\
(0.018)\end{array}$ & $\begin{array}{l}0.011 * \\
(0.006)\end{array}$ & $\begin{array}{c}-0.412 \text { *** } \\
(0.018)\end{array}$ & $\begin{array}{c}-0.394 * * * \\
(0.019)\end{array}$ \\
\hline Culture & $\begin{array}{c}0.123^{* * *} \\
(0.020)\end{array}$ & $\begin{array}{c}0.127^{* * *} \\
(0.020)\end{array}$ & $\begin{array}{c}0.097^{* * *} \\
(0.020)\end{array}$ & $\begin{array}{c}0.952^{* * *} \\
(0.053)\end{array}$ & $\begin{array}{c}0.104^{* * *} \\
(0.020)\end{array}$ & $\begin{array}{c}0.998^{* * *} \\
(0.054)\end{array}$ & $\begin{array}{c}0.941^{* * *} \\
(0.053)\end{array}$ \\
\hline Markopen & $\begin{array}{c}-0.373^{* * *} \\
(0.024)\end{array}$ & $\begin{array}{c}-0.355^{* * *} \\
(0.024)\end{array}$ & $\begin{array}{c}-0.368^{* * *} \\
(0.024)\end{array}$ & $\begin{array}{c}-0.196^{* * *} \\
(0.064)\end{array}$ & $\begin{array}{c}-0.351^{* * *} \\
(0.024)\end{array}$ & $\begin{array}{c}-0.230^{* * * *} \\
(0.064)\end{array}$ & $\begin{array}{c}-0.205^{* * *} \\
(0.064)\end{array}$ \\
\hline Markdyna & $\begin{array}{c}-0.132 * * * \\
(0.013)\end{array}$ & $\begin{array}{c}-0.133^{* * *} \\
(0.013)\end{array}$ & $\begin{array}{c}-0.119^{* * *} \\
(0.013)\end{array}$ & $\begin{array}{c}-0.454^{* * *} \\
(0.035)\end{array}$ & $\begin{array}{c}-0.122 * * * \\
(0.013)\end{array}$ & $\begin{array}{c}-0.409^{* * * *} \\
(0.035)\end{array}$ & $\begin{array}{c}-0.443^{* * *} \\
(0.035)\end{array}$ \\
\hline Phase & $\begin{array}{c}-0.781^{* * *} \\
(0.018)\end{array}$ & $\begin{array}{c}-0.750^{* * *} \\
(0.018)\end{array}$ & $\begin{array}{c}-0.777^{* * *} \\
(0.018)\end{array}$ & $\begin{array}{c}0.040 \\
(0.053)\end{array}$ & $\begin{array}{c}-0.748^{* * *} \\
(0.018)\end{array}$ & $\begin{array}{c}-0.095 \text { * } \\
(0.050)\end{array}$ & $\begin{array}{c}-0.126^{* *} \\
(0.049)\end{array}$ \\
\hline Firm age & $\begin{array}{c}-0.090^{* * *} \\
(0.007)\end{array}$ & $\begin{array}{c}-0.084^{* * *} \\
(0.007)\end{array}$ & $\begin{array}{c}-0.086^{* * *} \\
(0.007)\end{array}$ & $\begin{array}{c}0.038 \\
(0.064)\end{array}$ & $\begin{array}{c}-0.081^{* * *} \\
(0.007)\end{array}$ & $\begin{array}{c}-0.128^{* * *} \\
(0.019)\end{array}$ & $\begin{array}{c}-0.152^{* * *} \\
(0.019)\end{array}$ \\
\hline
\end{tabular}


Table 3. Cont.

\begin{tabular}{cccccccc}
\hline Variables & Model 1 & Model 2 & Model 3 & Model 4 & Model 5 & Model 6 & Model 7 \\
\hline Size & $-0.153^{* * *}$ & $-0.180^{* * *}$ & $-0.155^{* * *}$ & $0.111^{* *}$ & $-0.181^{* * *}$ & 0.017 & $0.060^{* * *}$ \\
& $(0.008)$ & $(0.008)$ & $(0.008)$ & $(0.047)$ & $(0.008)$ & $(0.021)$ & $(0.021)$ \\
Owners & $0.275^{* * *}$ & $0.237^{* * *}$ & $0.276^{* * *}$ & $-0.118^{* *}$ & $0.239^{* * *}$ & -0.037 & $-0.053^{*}$ \\
& $(0.011)$ & $(0.011)$ & $(0.011)$ & $(0.049)$ & $(0.011)$ & $(0.030)$ & $(0.030)$ \\
Age & $-0.003^{* * *}$ & $-0.003^{* * *}$ & $-0.003^{* * *}$ & $-0.149^{* * *}$ & $-0.002^{* * *}$ & $-0.009^{* * *}$ & $-0.010^{* * *}$ \\
& $(0.000)$ & $(0.000)$ & $(0.000)$ & $(0.019)$ & $(0.000)$ & $(0.001)$ & $(0.001)$ \\
Gender & $-0.127^{* * *}$ & $-0.110^{* * *}$ & $-0.125^{* * *}$ & $-0.079^{* * *}$ & $-0.108^{* * *}$ & $-0.068^{* *}$ & $-0.082^{* * *}$ \\
& $(0.011)$ & $(0.011)$ & $(0.011)$ & $(0.029)$ & $(0.011)$ & $(0.030)$ & $(0.029)$ \\
Reasonop & $0.151^{* * *}$ & $0.129^{* * *}$ & $0.144^{* * *}$ & $0.049^{* *}$ & $0.123^{* * *}$ & $0.241^{* * *}$ & $0.288^{* * *}$ \\
& $(0.011)$ & $(0.011)$ & $(0.011)$ & $(0.021)$ & $(0.011)$ & $(0.030)$ & $(0.029)$ \\
Risk & $0.114^{* * *}$ & $0.113^{* * *}$ & $0.100^{* * *}$ & $-0.067^{* *}$ & $0.101^{* * *}$ & $0.391^{* * *}$ & $0.513^{* * *}$ \\
& $(0.012)$ & $(0.011)$ & $(0.012)$ & $(0.030)$ & $(0.011)$ & $(0.031)$ & $(0.030)$ \\
Industry & $\sqrt{ }$ & $\sqrt{ }$ & $\sqrt{ }$ & $\sqrt{ }$ & $\sqrt{ }$ & $\sqrt{ }$ & $\sqrt{ }$ \\
Year & $\sqrt{ }$ & $\sqrt{ }$ & $\sqrt{ }$ & $\sqrt{ }$ & $\sqrt{ }$ & $\sqrt{ }$ & $\sqrt{ }$ \\
Constant & $2.040^{* * *}$ & $2.115^{* * *}$ & $1.895^{* * *}$ & $3.130^{* * *}$ & $1.990^{* * *}$ & $2.279^{* * *}$ & $3.039^{* * *}$ \\
& $(0.114)$ & $(0.112)$ & $(0.114)$ & $(0.302)$ & $(0.112)$ & $(0.309)$ & $(0.302)$ \\
Observations & 25,283 & 25,283 & 25,283 & 25,283 & 25,283 & 25,283 & 25,283 \\
\hline
\end{tabular}

${ }^{* * *} p<0.01,{ }^{* *} p<0.05,{ }^{*} p<0.1$.

\section{Conclusions and Discussion}

In this paper, we examined how social capital (network diversity) and human capital (prior entrepreneurial experience, education) jointly shape firm performance. We firstly predict that an entrepreneur's social network such as a market tie, private tie, international tie, professional tie, and workplace tie influence firm performance by providing more information, creative or from a heterogeneous perspective, as well as providing resources. In addition, drawing on cognition theory, we further tested the mediation effect of entrepreneurial alertness on the relationship between network diversity and venture growth. Moreover, the relationship between network diversity and entrepreneurial alertness was lower for entrepreneurs with prior entrepreneurial experience and higher educational levels. This study sheds light on the effect of diverse social networks on subsequent entrepreneurial alertness and venture growth by incorporating human capital factors. The findings have considerable theoretical implications for future research on social networks, entrepreneurial alertness, and venture growth.

First, we identified an important but not neglected mechanism that links the relationship between social capital and venture growth. The process through which entrepreneurs can impact venture growth is a core question in the field of entrepreneurship [63]. In fact, several approaches have been suggested in previous literature to explain it. For example, human resources [64], industry and startup experience [35], social capital [26], and an entrepreneur's capability [37] are factors that influence a venture's growth. However, these factors excessively focused on identifying the factors acting on venture growth, and thus resulted in a controversial conclusion with regards to these factors. This paper extends prior perspectives on the interaction of social capital and human capital regarding entrepreneurial alertness since it is the premise of a successful venture.

Second, we provide a new perspective to explore the relationship between social capital, human capital, and entrepreneurial activities. Cohen and Winn (2007) [65] proposed that opportunity is a key factor in predicting venture growth. However, extant studies usually explain how ventures can identity opportunity, and they suggest that entrepreneurial alertness, information asymmetry, prior knowledge, one's social network, and personality traits should interact with each other [21]. Our research integrates these factors from the perspective of pattern recognition. That is, a diverse network provides ventures with more information, resources, and perspectives to perceived opportunities, but they are replaceable by human capital, since entrepreneurs gain their pattern recognition ability both from formal education and information embedded in their social network and life experiences. 
We should note here that the negative interaction effect between the diverse network and education resolves the debate on the relationship between entrepreneurs' education and their entrepreneurial alertness. Although numerous studies have identified the benefit of education that provides individuals with basic skills or knowledge [50], others believe that a high level of education can also entail disadvantages [51], such as cognition inertia, risk aversion and the danger of being "locked-in" [2], especially in the scenario of academic entrepreneurship where entrepreneurs are highly educated but lack the basic capability or logic to be alert to potential opportunities [66].

The study has some limitations. First, due to the brief time frame, our choice of control variables may be limited. Future research could incorporate other variables that may have a potential impact on entrepreneurial opportunity alertness. For example, some scholars have suggested that personality might also influence entrepreneurial alertness [67]. Moreover, our measure of venture growth is based on the entrepreneurs' self-report; it is not the venture's actual growth. Much rich data could be used to test the theoretical framework of this study. Second, we only test our hypotheses by using cross-sectional data. To validate the causal relationship, longitudinal designs and other methods are needed in future research for theory generalization. Third, the use of five aspects of network diversity does not allow us to capture all ties of one's network. As a result, we are not able to know how an entrepreneur's position in the full network and how other network attributes, such as network centrality and the structural whole act on entrepreneurial alertness.

For entrepreneurs, the results suggest that entrepreneurial managers need to rely on different kinds of network ties to cultivate cognitive patterns. Given that diverse social networks play a critical role in venture performance, we suggest that entrepreneurs should develop different types of social tie, for instance, by cultivating relationships with customers, business partners, and venture capitalists. Entrepreneurs with high education levels will need to step out of their "small cycles" to make better use of outsourced information. Also, what diverse social networks provide, to some extent, is replaceable with human capital. Entrepreneurs should balance these two factors to construct their capability to be alert to potential opportunities. Furthermore, entrepreneurship is a "learning by trying" process; entrepreneurs with diverse social networks do benefit from diverse information. What is more important is how to leverage this information and how to transfer it as a capability to deal with diverse information. Lastly, most entrepreneurs highlight the importance of higher-educational members in their team; this could result in team homogeneity which might be harmful to venture growth. Diverse educational level members would be helpful in this regard.

Author Contributions: Conceptualization, J.L. and X.L.; Methodology, X.L. and W.Z.; Software, X.L.; Validation, X.L.; Formal analysis, W.Z.; Investigation, T.S.; writing-original draft preparation, X.L.; writing-review and editing, W.Z. and X.L.; Visulization, X.L.; supervision, J.L.; project administration, J.L.; funding acquisition, W.Z. All authors have read and agreed to the published version of the manuscript.

Funding: This research is funded by China MOST Torch High Technology Industry Development Center (2016DDJ1ZZ15) and Shaanxi Province Social Science Fund Project (2016R035).

Conflicts of Interest: The authors declare no conflict of interest.

\section{References}

1. Gulati, R.; Nohria, N.; Zaheer, A. Strategic networks. Strateg. Manag. J. 2000, 21, 203-215. [CrossRef]

2. Uzzi, B. Embeddedness in the Making of Financial Capital: How Social Relations and Networks Benefit Firms Seeking Financing. Am. Sociol. Rev. 1999, 64, 481-505. [CrossRef]

3. Bell, G.G. Clusters, networks, and firm innovativeness. Strateg. Manag. J. 2005, 26, 287-295. [CrossRef]

4. Singh, R.P.; Hills, G.E.; Lumpkin, G.; Hybels, R.C. The Entrepreneurial Opportunity Recognition Process: Examining the Role of Self-Perceived Alertness and Social Networks. Acad. Manag. Proc. 1999, 1999, G1-G6. [CrossRef]

5. Goerzen, A.; Beamish, P.W. The effect of alliance network diversity on multinational enterprise performance. Strateg. Manag. J. 2005, 26, 333-354. [CrossRef] 
6. Kale, P.; Dyer, J.H.; Singh, H. Alliance capability, stock market response, and long-term alliance success: The role of the alliance function. Strateg. Manag. J. 2002, 23, 747-767. [CrossRef]

7. Walter, A.; Auer, M.; Ritter, T. The Impact of Network Capabilities and Entrepreneurial Orientation on University Spin-off Performance*. Acad. Entrep. 2009, 9-45. [CrossRef]

8. Ritter, T.; Gemünden, H.G. Network competence: Its impact on innovation success and its antecedents. J. Bus. Res. 2003, 56, 745-755. [CrossRef]

9. Stinchcombe, A.L. Organizations and Social Structure. In Handbook of Organizations; March, J.G., Ed.; Rand McNally: Chicago, IL, USA, 1965.

10. Vissa, B.; Chacar, A.S. Leveraging ties: The contingent value of entrepreneurial teams' external advice networks on Indian software venture performance. Strateg. Manag. J. 2009, 30, 1179-1191. [CrossRef]

11. Davidsson, P.; Honig, B. The role of social and human capital among nascent entrepreneurs. J. Bus. Ventur. 2003, 18, 301-331. [CrossRef]

12. Kogut, B.; Zander, U. Knowledge of the Firm, Combinative Capabilities, and the Replication of Technology. Organ. Sci. 1992, 3, 383-397. [CrossRef]

13. Zahra, S.A.; Ireland, R.D.; Hitt, M.A. International Expansion by New Venture Firms: International Diversity, Mode of Market Entry, Technological Learning, and Performance. Acad. Manag. J. 2000, 43, 925-950.

14. Hoang, H.; Antoncic, B. Network-based research in entrepreneurship. J. Bus. Ventur. 2003, 18, $165-187$. [CrossRef]

15. Witt, P. Entrepreneurs' networks and the success of start-ups. Entrep. Reg. Dev. 2004, 16, 391-412. [CrossRef]

16. Beckman, C.M.; Haunschild, P.R. Network Learning: The Effects of Partners' Heterogeneity of Experience on Corporate Acquisition. Adm. Sci. Q. 2002, 47, 92-124. [CrossRef]

17. Rodan, S.; Galunic, C. More than network structure: How knowledge heterogeneity influences managerial performance and innovativeness. Strateg. Manag. J. 2004, 25, 541-562. [CrossRef]

18. Chavoushi, Z.H.; Zali, M.R.; Valliere, D.; Faghih, N.; Hejazi, R.; Dehkordi, A.M. Entrepreneurial alertness: A systematic literature review. J. Small Bus. Entrep. 2020, 1-30. [CrossRef]

19. Gaglio, C.M.; Katz, J.A. The psychological basis of opportunity identification: Entrepreneurial alertness. Small Bus. Econ. 2001, 16, 95-111. [CrossRef]

20. Baron, R.A.; Ward, T.B. Expanding entrepreneurial cognition's toolbox: Potential contributions from the field of cognitive science. Entrep. Theory Pract. 2004, 28, 553-573. [CrossRef]

21. Ardichvili, A.; Cardozo, R.; Ray, S. A theory of entrepreneurial opportunity identification and development. J. Bus. Ventur. 2003, 18, 105-123. [CrossRef]

22. Nikraftar, T.; Hosseini, E. Factors affecting entrepreneurial opportunities recognition in tourism small and medium sized enterprises. Tour. Rev. 2016, 71, 6-17. [CrossRef]

23. Ma, R.; Huang, Y.-C. Opportunity-Based Strategic Orientation, Knowledge Acquisition, and Entrepreneurial Alertness: The Perspective of the Global Sourcing Suppliers in China. J. Small Bus. Manag. 2016, 54, 953-972. [CrossRef]

24. Heffernan, G.M. Path Dependence, Behavioral Rules, and the Role of Entrepreneurship in Economic Change: The Case of the Automobile Industry. Rev. Austrian Econ. 2003, 16, 45-62. [CrossRef]

25. Tang, J. Exploring the Constitution of Entrepreneurial Alertness: The Regulatory Focus View. J. Small Bus. Entrep. 2012, 22, 221-238. [CrossRef]

26. Arenius, P.; Clercq, D.D. A Network-based Approach on Opportunity Recognition. Small Bus. Econ. 2005, 24, 249-265. [CrossRef]

27. Bhagavatula, S.; Elfring, T.; van Tilburg, A.; van de Bunt, G.G. How social and human capital influence opportunity recognition and resource mobilization in India's handloom industry. J. Bus. Ventur. 2010, 25, 245-260. [CrossRef]

28. Ma, R.; Huang, Y.-C.; Shenkar, O. Social networks and opportunity recognition: A cultural comparison between Taiwan and the United States. Strateg. Manag. J. 2011, 32, 1183-1205. [CrossRef]

29. Ozgen, E.; Baron, R.A. Social sources of information in opportunity recognition: Effects of mentors, industry networks, and professional forums. J. Bus. Ventur. 2007, 22, 174-192. [CrossRef]

30. Tang, J.; Kacmar, K.M.; Busenitz, L. Entrepreneurial alertness in the pursuit of new opportunities. J. Bus. Ventur. 2012, 27, 77-94. [CrossRef]

31. Dimov, D. Beyond the single-person, single-insight attribution in understanding entrepreneurial opportunities. Entrep. Theory Pract. 2007, 31, 713-731. [CrossRef] 
32. Shane, S. Prior knowledge and the discovery of entrepreneurial opportunities. Organ. Sci. 2000, 11, 448-469. [CrossRef]

33. Kilgour, M.; Koslow, S. Why and how do creative thinking techniques work?: Trading off originality and appropriateness to make more creative advertising. J. Acad. Mark. Sci. 2009, 37, 298-309. [CrossRef]

34. Estrin, S.; Mickiewicz, T.; Stephan, U. Human capital in social and commercial entrepreneurship. J. Bus. Ventur. 2016, 31, 449-467. [CrossRef]

35. Cassar, G. Industry and startup experience on entrepreneur forecast performance in new firms. J. Bus. Ventur. 2014, 29, 137-151. [CrossRef]

36. Dimov, D. Nascent Entrepreneurs and Venture Emergence: Opportunity Confidence, Human Capital, and Early Planning. J. Manag. Stud. 2010, 47, 1123-1153. [CrossRef]

37. Shu, R.; Ren, S.; Zheng, Y. Building networks into discovery: The link between entrepreneur network capability and entrepreneurial opportunity discovery. J. Bus. Res. 2018, 85, 197-208. [CrossRef]

38. Ucbasaran, D.; Westhead, P.; Wright, M. Opportunity identification and pursuit: Does an entrepreneur's human capital matter? Small Bus. Econ. 2008, 30, 153-173. [CrossRef]

39. Chatterji, A.K. Spawned with a silver spoon? Entrepreneurial performance and innovation in the medical device industry. Strateg. Manag. J. 2009, 30, 185-206. [CrossRef]

40. Shane, S.; Khurana, R. Bringing individuals back in: The effects of career experience on new firm founding. Ind. Corp. Chang. 2003, 12, 519-543. [CrossRef]

41. Ajzen, I. The theory of planned behavior. Organ. Behav. Hum. Decis. Process. 1991, 50, 179-211. [CrossRef]

42. Bandura, A. Self-efficacy: Toward a Unifying Theory of Behavioral Change. Psychol. Rev. 1997, 84, $191-215$. [CrossRef]

43. Li, H.; Zhang, Y. The role of managers' political networking and functional experience in new venture performance: Evidence from China's transition economy. Strateg. Manag. J. 2007, 28, 791-804. [CrossRef]

44. Eisenhardt, K.M.; Schoonhoven, C.B. Organizational Growth: Linking Founding Team, Strategy, Environment, and Growth Among U.S. Semiconductor Ventures, 1978-1988. Adm. Sci. Q. 1990, 35, 504-529. [CrossRef]

45. Child, J.; Markoczy, L. Host-country managerial behaviour and learning in Chinese and Hungarian joint ventures. J. Manag. Stud. 1993, 30, 611-631. [CrossRef]

46. Barro, R.J.; Lee, J.W. A new data set of educational attainment in the world, 1950-2010. J. Dev. Econ. 2013, 104, 184-198. [CrossRef]

47. Bhagat, S.; Bolton, B.; Subramanian, A. CEO Education, CEO Turnover, and Firm Performance; Social Science Electronic Publishing, Inc.: Rochester, NY, USA, 2010; SSRN 1670219.

48. Hovne, A.S.; Hovne, B.S.; Schøtt, T. Entrepreneurs' innovation benefitting from their education and training and from national policy and culture: A global study. Int. J. Entrep. Small Bus. 2014, 23, 127-144. [CrossRef]

49. Fernández-Pérez, V.; Alonso-Galicia, P.E.; Rodríquez-Ariza, L.; Fuentes-Fuentes, M.d.M. Professional and personal social networks: A bridge to entrepreneurship for academics? Eur. Manag. J. 2015, 33, 37-47. [CrossRef]

50. Hatch, N.W.; Dyer, J.H. Human capital and learning as a source of sustainable competitive advantage. Strateg. Manag. J. 2004, 25, 1155-1178. [CrossRef]

51. Casson, M. Entrepreneurship, business culture and the theory of the firm. In Handbook of Entrepreneurship Research; Springer: Berlin/Heidelberg, Germany, 2013; pp. 223-246.

52. Milliken, F.J. Three types of perceived uncertainty about the environment: State, effect, and response uncertainty. Acad. Manag. Rev. 1987, 12, 133-143. [CrossRef]

53. Reynolds, P.; Bosma, N.; Autio, E.; Hunt, S.; De Bono, N.; Servais, I.; Chin, N. Global Entrepreneurship Monitor: Data Collection Design and Implementation 1998-2003. Small Bus. Econ. 2005, 24, 205-231. [CrossRef]

54. Baron, R.M.; Kenny, D.A. The moderator-mediator variable distinction in social psychological research: Conceptual, strategic, and statistical considerations. J. Personal. Soc. Psychol. 1986, 51, 1173. [CrossRef]

55. Sobel, M.E. Asymptotic Confidence Intervals for Indirect Effects in Structural Equation Models. Sociol. Methodol. 1982, 13, 290. [CrossRef]

56. Brush, C.G.; Vanderwerf, P.A. A comparison of methods and sources for obtaining estimates of new venture performance. J. Bus. Ventur. 1992, 7, 157-170. [CrossRef]

57. Baum, J.R.; Locke, E.A. The relationship of entrepreneurial traits, skill, and motivation to subsequent venture growth. J. Appl. Psychol. 2004, 89, 587. [CrossRef] [PubMed] 
58. Blau, P.M. Inequality and Heterogeneity: A primitive Theory of Social Structure; Free Press: New York, NY, USA, 1977; Volume 7.

59. Levie, J.; Autio, E. A theoretical grounding and test of the GEM model. Small Bus. Econ. 2008, 31, $235-263$. [CrossRef]

60. Chatterjee, A.; Hambrick, D.C. It's all about me: Narcissistic chief executive officers and their effects on company strategy and performance. Adm. Sci. Q. 2007, 52, 351-386. [CrossRef]

61. Shannon, C.E.; Weaver, W.; Burks, A.W. The Mathematical Theory of Communication; University of Illinois Press: Champaign, IL, USA, 1951.

62. Dutta, S. Creating in the crucibles of nature's fury: Associational diversity and local social entrepreneurship after natural disasters in California, 1991-2010. Adm. Sci. Q. 2017, 62, 443-483. [CrossRef]

63. Shane, S.; Venkataraman, S. The promise of entrepreneurship as a field of research. Acad. Manag. Rev. 2000, 25, 217-226. [CrossRef]

64. Florin, J.; Lubatkin, M.; Schulze, W. A Social Capital Model of High-Growth Ventures. Acad. Manag. J. 2003, 46, 374-384.

65. Cohen, B.; Winn, M.I. Market imperfections, opportunity and sustainable entrepreneurship. J. Bus. Ventur. 2007, 22, 29-49. [CrossRef]

66. Balven, R.; Fenters, V.; Siegel, D.S.; Waldman, D. Academic Entrepreneurship: The Roles of Identity, Motivation, Championing, Education, Work-Life Balance, and Organizational Justice. Acad. Manag. Perspect. 2018, 32, 21-42. [CrossRef]

67. Obschonka, M.; Hakkarainen, K.; Lonka, K.; Salmela-Aro, K. Entrepreneurship as a twenty-first century skill: Entrepreneurial alertness and intention in the transition to adulthood. Small Bus. Econ. 2017, 48, 487-501. [CrossRef]

Publisher's Note: MDPI stays neutral with regard to jurisdictional claims in published maps and institutional affiliations. 